\title{
Antibiotic resistance profiles of vancomycin resistant enterococci in chicken meat samples
}

\author{
Bahar ONARAN ${ }^{\mathrm{a}, \bigotimes}$, Muammer GÖNCÜOĞLU ${ }^{\mathrm{b}}$, Fatma Seda BİLİR ORMANCI ${ }^{\mathrm{c}}$ \\ Ankara University, Faculty of Veterinary Medicine, Department of Food Hygiene and Technology, Ankara, Turkey. \\ aOORCID: 0000-0002-3515-7548; ' ${ }^{\mathrm{O} O R C I D: ~ 0000-0001-7245-1941 ; ~ ' ~ O R C I D: ~ 0000-0003-3614-4666 . ~}$ \\ Correponding author: bonaran@ankara.edu.tr \\ Received date: 07.08.2018- Accepted date: 14.06.2019
}

\begin{abstract}
Antibiotic resistance is one of the serious threats to global public health and food safety today. Acquired antibiotic resistance in microorganisms arises from prevalent use of antibiotics for human and animal medicine. Owing to the fact that Vancomycin Resistant Enteroccocci (VRE) is a vital problem for public health, determination of the antibiotic resistance profiles of Enterococcus spp. isolates have crucial importance as a part of the farm to fork food safety. In the study, 120 retail chicken meat samples were analyzed, and $36(30 \%)$ of the samples were detected as Enterococcus spp. positive. According to the results, the most prevalent species was E. faecalis with a rate of $44.4 \%$ (16/36), followed by $27.8 \%$ (10/36) E. faecium, $11.1 \%$ (4/36) E. durans, $2.8 \%$ (1/36) E. gallinarum and 2.8\% (1/36) E. casseliflavus. Antibiotic resistance profiles of the verified Enterococcus spp. isolates were determined with disc diffusion method in terms of eight different antibiotics. Among the Enterococcus spp. isolates, 20 (55.5\%) isolates were phenotypically resistant to vancomycin, 6 isolates (16.7\%) were detected as vanA positive, 3 isolates $(8.3 \%)$ were detected as vanB positive, and one isolate ( $5 \%$ ) showed high resistance to vancomycin (MIC $>256 \mu \mathrm{g} / \mathrm{ml}$ ). Even though the observed percentages are low, the observed resistance patterns are still of concern for public health.
\end{abstract}

Keywords: Chicken meat, E. faecalis, E. faecium, vanA, vanB.

\section{Tavuk eti örneklerinde vankomisin dirençli enterokokların antibiyotik direnç profilleri}

Özet: Günümüzde antibiyotik direnci, halk sağlığı ve gıda güvenliğini küresel anlamda tehdit eden ciddi problemlerden birisidir. Mikroorganizmalarda oluşan antibiyotik direnci, başlıca insan ve hayvan infeksiyonlarında antibiyotiklerin yaygın olarak kullanılmasından kaynaklanmaktadır. Vankomisin dirençli enterokokların (VRE) halk sağlı̆̆ açısından hayati bir sorun teşkil etmeleri nedeniyle, Enterococcus spp. izolatlarının antibiyotik direnç profillerinin belirlenmesi çiftlikten sofraya gıda güvenliği kapsamında kritik öneme sahiptir. Çalışmada, perakende olarak satışa sunulan 120 tavuk eti örneği analiz edilmiş ve örneklerin 36 (\%30)'s1 Enterococcus spp. pozitif olarak izole edilmiştir. İzolatlar arasında en yayın tür \%44,4 (16/36) oranla E. faecalis olmuş, bunu \%27,8 (10/36) ile E. faecium, \%11.1 (4/36) ile E. durans, \%2,8 (1/36) ile E. gallinarum ve \%2,8 ile (1/36) E. casseliflavus olarak identifiye edilmiştir. Enterococcus spp. izolatlarının antibiyotik direnç profilleri sekiz farklı antibiyotik yönünden disk difüzyon metodu kullanılarak belirlenmiştir. Enterococcus spp. izolatlarından 20'si (\%55,5) fenotipik olarak vankomisine dirençli, $6(\% 16,7)$ izolat vanA pozitif, $3(\% 8,3)$ izolat ise vanB pozitif olarak belirlenmiş, bir (\%5) izolatın ise vankomisine karşı yüksek seviye dirençli (MIK > 256 $\mu \mathrm{g} / \mathrm{ml}$ ) olduğu saptanmıştır. Belirlenen yüzdeler düşük olmasına rağmen, tespit edilen direnç profillerinin halk sağlığı açısından risk teşkil edecek düzeyde olduğu görülmektedir.

Anahtar sözcükler: E. faecalis, E. faecium, tavuk eti, vanA, vanB.

\section{Introduction}

Increasing antibiotic resistance in microorganisms arisen from prevalent and inaccurate use of antibiotics, is a serious threat to global public health and food safety. According to the Centers for Disease Control and Prevention (CDC) report in 2013, at least 2 million people are infected with microorganisms that are resistant to one or more antibiotics designed to treat those infections. In addition, it is pointed out that in the United States, at least
23,000 deaths occur as a direct cause of these antibiotic resistant infections (4).

Vancomycin resistance is the most prevalent antimicrobial resistant phenotype in enterococci. The importance of vancomycin arising from its use for the elimination of multidrug resistant strains or the treatment of patients allergic to antibiotics like ampicillin and penicillin. Besides it is used frequently in nosocomial infections as a last resort antibiotic, resistance genes can 
be transferred to humans via foods. According to CDC, an estimated 66,000 healthcare-associated Enterococcus spp. infections occur in the United States and overall 20,000 VRE infections occurred among hospitalized patients each year, with approximately 1,300 deaths. Additionally, $E$. faecalis and E. faecium are the most isolated species from enterococcal infections $(4,9)$.

Growing concerns about risks to public health have heightened consumer awareness of safety in retail chicken meat consumption. Retail chicken meats are commonly contaminated with Enterococcus spp., and increasing interest on the epidemiology of these bacteria continues worldwide (23). In Turkey, there is a little information about antimicrobial resistance profiles, resistance gene distribution and incidence of Enterococcus spp. from poultry meat so that kind of information is a prominent need for food safety and public health.

The objectives of this study were to isolate and identify Enterococcus spp. from retail chicken meat samples collected from Ankara markets, to evaluate the antibiotic resistance profiles of the verified Enterococcus spp. isolates, to determine vanA and vanB resistance phenotypes of the species identified as E. faecalis and $E$. faecium, to analyze MIC (Minimum Inhibitory Concentration) values of the isolates determined as vancomycin resistant.

\section{Material and Methods}

Bacterial strains: As positive control strains; E. faecalis WHO3 (vanA $\left.{ }^{+}\right)$, E. faecalis ATCC 29212, E. faecium tetM 7003, E. faecalis WHO14 (vanB $\left.{ }^{+}\right)$, E. gallinarum C30BR, E. hirae (wild type), and E. durans (wild type) were used in PCR analysis.

Collection of samples: From different markets located at Ankara in Turkey, 120 retail chicken meat samples were obtained in unpackaged and packaged form, during the years 2013-2014. Samples were transported to the laboratory in cold chain, and examined for enterococci in two hours.

Isolation of enterococci: With the amount of $90 \mathrm{ml}$, sterile buffered peptone water (Oxoid, CM0009, Thermo Scientific) were added into the $10 \mathrm{~g}$ of each chicken meat samples and they were homogenized for $2 \mathrm{~min}$. Afterwards, $0.1 \mathrm{ml}$ of the homogenate was plated on Slanetz and Bartley medium (Oxoid, CM0377A, Thermo Scientific) and incubated for $24-48 \mathrm{~h}$ at $37^{\circ} \mathrm{C}$. Then, typical colonies were transmitted into $0.6 \%$ yeast extract powder (Oxoid, L0021, Thermo Scientific) enriched tryptone soya agar (Oxoid, CM0131, Thermo Scientific) and subjected to biochemical tests according to Manero and Blanch (21).

Identification of enterococci: Chelex-100 resin based technique was used as to the DNA extraction and Enterococcus spp. isolates were identificated according to the determination of tuf gene (Table 1). PCR procedure was performed according to Kasımoğlu Doğru et al. (16).

Two different multiplex PCR were carried out for the verification of E. faecium, E. faecalis, E. gallinarum according to Kariyama et al. (15); E. durans, and E. hirae according to Jackson et al. (14). Primer pairs used in the PCR analysis were shown in Table 1.

Table 1. Target genes used in PCR analysis.

\begin{tabular}{|c|c|c|c|}
\hline Target gene & Primer sequence $\left(5^{\prime}-3^{\prime}\right)$ & Product size (bp) & Reference \\
\hline tuf & $\begin{array}{l}\text { Ent1:TACTGACAAACCATTCATGATG } \\
\text { Ent2:AACTTCGTCACCAACGCGAAC }\end{array}$ & 112 & 17 \\
\hline$d d l_{\text {E.faecalis }}$ & $\begin{array}{l}\text { ddlE1:ATCAAGTACAGTTAGTCTTTATTAG } \\
\text { ddlE2:ACGATTCAAAGCTAACTGAATCAGT }\end{array}$ & 941 & 15 \\
\hline$d d l_{E . \text { faecium }}$ & $\begin{array}{l}\text { ddlF1:TTGAGGCAGACCAGATTGACG } \\
\text { ddlF2:TATGACAGCGACTCCGATTCC }\end{array}$ & 658 & 15 \\
\hline van $\mathrm{C}_{1 E \text {. gallinarum }}$ & $\begin{array}{l}\text { C1:GGTATCAAGGAAACCTC } \\
\text { C2:CTTCCGCCATCATAGCT }\end{array}$ & 822 & 7 \\
\hline$d d l_{E . \text { durans }}$ & $\begin{array}{l}\text { DU1:CCTACTGATATTAAGACAGCG } \\
\text { DU2:TAATCCTAAGATAGGTGTTTG }\end{array}$ & 295 & 14 \\
\hline$d d l_{E \text {. hirae }}$ & $\begin{array}{l}\text { HI1:CTTTCTGATATGGATGCTGTC } \\
\text { HI2:TAAATTCTTCCTTAAATGTTG }\end{array}$ & 187 & 14 \\
\hline $\operatorname{Van} \mathrm{A}$ & $\begin{array}{l}\text { A1:CATGAATAGAATAAAAGTTGCAATA } \\
\text { A2:CCCCTTTAACGCTAATACGATCAA }\end{array}$ & 1030 & 15 \\
\hline $\operatorname{Van} \mathrm{B}$ & $\begin{array}{l}\text { B1:GTGACAAACCGGAGGCGAGGA } \\
\text { CCGCCATCCTCCTGCAAAAAA }\end{array}$ & 433 & 15 \\
\hline
\end{tabular}


Determination of antibiotic resistance profiles: As defined by the Clinical and Laboratory Standards Institute (5), disc diffusion method was used for the determination of phenotypic antibiotic resistance of Enterococcus spp. isolates against eight antibiotics. Chloramphenicol (30 $\mu \mathrm{g}$, Oxoid CT0013B, Thermo Scientific), erythromycin (15 $\mu \mathrm{g}$, Oxoid CT0020B, Thermo Scientific), gentamicin (120 $\mu \mathrm{g}$, Oxoid CT0794B, Thermo Scientific), penicillin (10 U, Oxoid CT0043B, Thermo Scientific), streptomycin (300 $\mu \mathrm{g}$, Oxoid CT1897B, Thermo Scientific), vancomycin (30 $\mu \mathrm{g}$, Oxoid CT0058B, Thermo Scientific), linezolid (30 $\mu \mathrm{g}$, Oxoid CT1650B, Thermo Scientific), quinupristin/ dalfopristin (15 $\mu \mathrm{g}$, Oxoid CT1644B, Thermo Scientific) were used within this context.

\section{Determination of Minimal Inhibition}

Concentration (MIC) values: MIC values of the isolates were determined by E-test method against vancomycin by using swab technique. E-test strips (Oxoid, MA0102F, Thermo Scientific) were placed on Mueller-Hinton agar (Oxoid, CM0337B, Thermo Scientific) plates and were incubated at $35^{\circ} \mathrm{C}$ for $24-48 \mathrm{~h}$. After incubation, MIC values were evaluated according to the CLSI standarts (5) as; for VRE is $\geq 32 \mu \mathrm{g} / \mathrm{ml}$, for vancomycin succeptible enterococci is $\leq 4 \mu \mathrm{g} / \mathrm{ml}$.

Detection of vanA, and vanB genes: Gene specific primers for $v a n A$, and $v a n B$ used in the multiplex PCR assays are shown in Table 1 . PCR procedures were performed according to Kariyama et al. (15).

\section{Results}

In the study, among 120 retail chicken meat samples, $36(30 \%)$ of the samples were found positive for Enterococcus spp. Among enterococci, E. faecalis was the most prevalent species with a ratio of $44.4 \%$ (16/36), followed by $27.8 \%$ (10/36) E. faecium, $11.1 \%$ (4/36) $E$. durans, $2.8 \%$ (1/36) E. gallinarum. None of the isolates were confirmed as E. hirae, while one (2.8\%) isolate was confirmed as E. casseliflavus with biochemical tests.

According to the antibiotic resistance profiles of the verified Enterococcus spp. isolates all of the isolates were determined as intermediate or resistant to at least one antibiotic. According to the antibiotic resistance profiles of the isolates; $72.2 \%(26 / 36)$ of the isolates were resistant to three and more antibiotics, $19.4 \%$ (7/36) were resistant to five and more antibiotics, and $2.8 \%$ (1/36) were resistant to all of the antibiotics and $55.5 \%$ (20/36) of the isolates were resistant to vancomycin. Antibiotic resistance profiles of VRE isolates are shown in Table 2. On the other hand, number of resistant and susceptible VRE isolates in view of vancomycin MIC values are shown in Table 3.

According to the results, vanA genes were detected in $16.7 \%(6 / 36)$ of the Enterococcus spp. isolates, while $v a n B$ genes were detected in $8.3 \%(3 / 36)$ of them. One of the isolates was positive for both $v a n A$ or $v a n B$ genes and was determined as E. faecalis.

Table 2. Antibiotic resistance percentages of the VRE isolates (\%).

\begin{tabular}{|c|c|c|c|c|c|c|c|c|c|c|c|c|c|c|c|c|c|c|c|}
\hline \multirow{2}{*}{\multicolumn{2}{|c|}{$\begin{array}{l}\text { Number of } \\
\text { isolates }\end{array}$}} & \multicolumn{3}{|c|}{ LZD } & \multicolumn{3}{|c|}{ QD } & \multicolumn{3}{|c|}{ C } & \multicolumn{3}{|c|}{$\mathrm{CN}$} & \multicolumn{3}{|c|}{$\mathbf{P}$} & \multicolumn{3}{|c|}{$\mathbf{S}^{*}$} \\
\hline & & $\mathbf{R}$ & I & $\mathbf{S}$ & $\mathbf{R}$ & I & $\mathbf{S}$ & $\mathbf{R}$ & I & $\mathbf{S}$ & $\mathbf{R}$ & I & $\mathbf{S}$ & $\mathbf{R}$ & I & $\mathbf{S}$ & $\mathbf{R}$ & I & $\mathbf{S}$ \\
\hline Efa & 14 & $6(43)$ & $6(43)$ & $2(14)$ & $14(100)$ & - & - & $2(14)$ & $9(64)$ & $3(21)$ & 1(7) & 1(7) & $12(86)$ & $2(14)$ & - & $12(86)$ & $4(29)$ & $1(7)$ & $9(64)$ \\
\hline Efec & 2 & - & $2(100)$ & - & $2(100)$ & - & - & - & $2(100)$ & - & - & - & $2(100)$ & - & - & $2(100)$ & - & - & $2(100)$ \\
\hline $\mathrm{Du}$ & 2 & $1(50)$ & $1(50)$ & - & $2(100)$ & - & - & $1(50)$ & $1(50)$ & - & $1(50)$ & $1(50)$ & - & $1(50)$ & - & $1(50)$ & $1(50)$ & - & $1(50)$ \\
\hline Gal & 1 & $1(100)$ & - & - & $1(100)$ & - & - & $1(100)$ & - & - & $1(100)$ & - & - & - & - & 1(100) & $1(100)$ & - & - \\
\hline ND & 1 & - & 100 & - & $1(100)$ & - & - & - & $1(100)$ & - & - & - & $1(100)$ & - & - & $1(100)$ & - & - & $1(100)$ \\
\hline Total & 20 & $8(40)$ & $10(50)$ & $2(10)$ & $20(100)$ & - & - & $4(20)$ & $13(93)$ & $3(21)$ & $3(21)$ & $2(10)$ & $15(75)$ & $3(21)$ & - & $17(85)$ & $6(43)$ & $1(5)$ & $13(93)$ \\
\hline
\end{tabular}

Efa: E. faecalis; Efec: E. faecium; Du: E. durans; Gal: E. gallinarum; ND: Not Determined; LZD: Linezolid; QD: QuinupristinDalfopristin; C: Chloramphenicol; CN: Gentamicin; P: Penicillin; S*: Streptomycin; R: Resistant; I: Intermediate; S: Susceptible

Table 3. Number of resistant and susceptible VRE isolates in view of vancomycin MIC values, according to the CLSI standarts.

\begin{tabular}{|c|c|c|c|c|}
\hline MIC $(\mu \mathrm{g} / \mathrm{ml})$ & Resistance profile & Number of isolates & Isolated species & Van gene \\
\hline$\geq 32$ & $\mathrm{R}$ & 1 & $\mathrm{Du}$ & - \\
\hline $8-16$ & I & 4 & $\begin{array}{l}\text { Efa (3), } \\
\text { Efec (1) }\end{array}$ & $\operatorname{vanA}(2)$ \\
\hline$\leq 4$ & S & 15 & $\begin{array}{l}\text { Efa (11), Efec (1), } \\
\text { Gal (1), Du (1), ND (1) }\end{array}$ & $\begin{array}{l}\operatorname{van} A(3) \\
\operatorname{van} B(1) \\
\operatorname{van} A+\operatorname{van} B(1)\end{array}$ \\
\hline
\end{tabular}

Efa: E. faecalis; Efec: E. faecium; Du: E. durans; Gal: E. gallinarum; ND: Not Determined 


\section{Discussion and Conclusion}

The consumption of food contamined with antibiotic resistant enterococci strains, is considered a probable path of transport of this agent from animals to humans (19). In this study, $30 \%$ of the chicken samples were found positive for Enterococcus spp., also Pesavento et al. (23) had similar results (28.6\%) in terms of Enterococcus spp. existence in chicken meat. Lower prevalences have been reported from Tunisia (19) and Greece (12) with the percentages of $24.5 \%$ and $21.7 \%$, in contrast higher prevalences have been reported from Brazil (8) and Tennessee (18) with $56.8 \%$ and $82.2 \%$ of Enterococcus spp. contamination, respectively. Besides, according to our results, $30.8 \%$ of the packaged and $29.6 \%$ of the unpackaged samples were contaminated with Enterococcus spp.

In our study, the most prevalent species were determined as E. faecalis, followed by E. faecium, E. durans, E. gallinarum and E. casseliflavus. Similar preponderances from chicken meat samples have been reported previously from Tunisia (19), Brazil (8), USA (25), in contrast, some other studies from Scandinavia, Spain and Italy (6), Greece (12), E. faecium was stated as of the preponderant species. Varieties of preponderances can be linked with geographical diversities or typing techniques $(14,21)$.

According to our study, all the isolates were determined as resistant or intermediate to at least one antibiotic used in study and which is a significant public health concern. Goncuoglu et al. (11) also implied that ongoing surveillance and antibiotic resistance of foodborne pathogens in the food chain is essential due to the public health implementations. Besides, by the reason of high antibiotic resistance profiles, it is very crucial to analyze antibiotic profiles of the isolates.

In some other studies, it is also determined that poultry isolates had similar antibiotic resistance profiles to similar group of antibiotics with that of our isolates (1417). Outcomes of this study pointed out the crucial importance regarding high level aminoglycoside resistance in poultry originated enterococci, that is quite low in Europe $(6,24)$. As aminoglycosides are considered as an option for enterococcal infections treatments, the contingency of the spread of the resistance via food food chain is minacious. In contrast to Europe, high level aminoglycoside resistance in enterococci prevalent in USA is similar to our results. Hayes et al. (13) analyzed the incidence of aminoglycoside resistance of $E$. gallinarum (56\%), E. faecium (58\%), and with the highest rate of E. casseliflavus (86\%). Although the use of avoparcin was banned in Turkey in 2002 (3), VRE can still be isolated from chicken meat. Besides, resistance to quinupristin-dalfopristin was observed in $27 \%$ of $E$. faecium isolates from chicken samples while all of the VRE isolates were resistant to this antibiotic in our study. Due to the significance of quinupristin-dalfopristin was the initial antibiotic certificated by the US Food and Drug Administration (FDA) for VRE infections, the resistance to this antibiotic has crucial importance for public health.

Linezolid is also the first commercially available drug of the group of the oxazolidinones and the other antibiotic also approved by FDA to treat infections caused by VRE (10). In our study 90\% (18/20) of the VRE isolates were intermediate or resistant to linezolid and it also provides an alarming warning about treatment of VRE infections. As part of the NARMS (National Antimicrobial Resistance Monitoring System), Tyson et al. (25) evaluated several retail meat commodities from 2002 to 2014, and found $92 \%$ of enterococci contamination. According to their study, none of the isolates was resistant to vancomycin, but only one isolate was resistant to linezolid, and resistance to tigecycline was below $1 \%$. In contrast, E. faecalis and E. faecium isolates were resistant to tetracycline with the percentages of $67.5 \%$ and $53.7 \%$, respectively.

In studies conducted in Turkey, Kasimoglu Dogru et al. (16) analyzed 106 chicken neck skin samples and their results are similar to our results, they determined majority $(90 \%)$ of enterococci isolates were high level resistant to tetracycline and erythromycin. Unlike to our results, they stated that all their isolates were susceptible against penicillin G. In another study, Yilmaz et al. (26) analyzed 105 isolates collected from chicken meat samples, they stated that the majority $(96 \%)$ of the samples were resistant to at least one antibiotic among tested twelve antibiotics. For the isolates from chicken samples, resistance percentages against tetracycline, erythromycin, ciprofloxacin, and trimethoprim/sulfamethoxazole antibiotics were $89.5 \%, 59 \%, 35.2 \%, 34.3 \%$, respectively. In this study, five strains were phenotypically resistant to vancomycin and also carried vanA gene besides, all VRE isolates were found to be resistant against trimethoprim/sulfamethoxazole, penicillin, tetracycline, ampicillin, and erythromycin. In contrast, Pesavento et al. (23) analyzed lower rates of enterococci were resistant to amoxicillin-clavulanic acid (0.32\%), linezolid (0.32\%), teicoplanin $(2.24 \%)$, and vancomycin $(3.53 \%)$. Higher rates were determined in E. faecalis isolates against tetracycline $(60.6 \%)$ and gentamicin $(21.9 \%)$. Generally, E. faecalis isolates stated to be more resistant that of $E$. faecium, similar with our results.

Lopez et al. (20) analyzed 129 chicken meat samples and determined $17.82 \%$ of them as VRE, indicated lower percentages $(55.5 \%)$ as compared to our study. Besides, according to CDC report, in United States, about $30 \%$ of healthcare-associated infections were related vancomycin 
resistant enterococci in 2013 (23). According to E-test results conducted in our study, one isolate $(5 \%)$ showed high resistance to vancomycin (MIC: $>256 \mu \mathrm{g} / \mathrm{ml}$ ). On the other hand, Lopez et al. (20) stated that among VRE isolates, $7(5.4 \%)$ isolates showed high resistance to vancomycin (MIC: 64-128 $\mu \mathrm{g} / \mathrm{ml}$ ). Besides, VRE isolates harboured five vanA and one vanB genes, while in our study, vanA genes were detected in six isolates and three of the isolates were harboured $v a n B$ genes.

In our study, twenty $(55.5 \%)$ isolates were phenotypically but eight $(22.2 \%)$ isolates were genotypically resistant to vancomycin. These differences of phenotypic and genotypic resistance to vancomycin in the studies can be attributed to the vancomycin resistance genotypes not limited only vanA and vanB. However, genes regarding vancomycin resistance for enterococci are defined as vanA, $-B,-C,-D,-E,-G,-L,-M$, and $N$, to date (2).

Messi et al. (22) analyzed 45 poultry isolates and 15 $(33.3 \%)$ isolates determined as VRE, whereas 4 isolates $(8.9 \%)$ contained vanA, $2(4.4 \%)$ isolates contained vanB, $9(20 \%)$ isolates contained vanC genes. In contrast, Aarestrup et al. (1) analyzed 126 chicken meat samples, and $10 \%$ of the samples identified as VRE. It is also stated that all VRE isolates were E. faecium. Vancomycin resistance is associated with sequences related to vanC genes are specific for E. gallinarum and E. casseliflavus (7). Therefore, E. gallinarum ve E. casseliflavus isolates also might be considered as harbouring van $C$ genes, in our study.

The study shows that VRE isolates from chicken meat in Turkey based on a high prevalence of resistance to antibiotics. By virtue of the fact that, VRE is a vital issue for global public health, determination of the antibiotic resistance profiles of Enterococcus spp. isolates have crucial importance as a part of the farm to fork food safety. Potential solutions should include efficient control survey programs for determining the enterococci in environmental sources and especially in food for preventing the spread of the pathogenic strains. Provided that the contamination with enterococci from different sources can be verified and limited, a rise in the prevalence of colonisation and infection amongst the hospitalised patients and also antibiotic resistance could be controlled. Longterm policies should be based on international survey systems in terms of monitoring the contamination in carcasses, foods, animals, and humans.

\section{Acknowledgements}

This study was supported by TUBITAK (The Scientific and Technological Research Council of Turkey) with Project no:113Z407. Besides, the study includes the data of first author's $\mathrm{PhD}$ thesis.

\section{Conflict of Interest}

The authors declared that there is no conflict of interest.

\section{References}

1. Aarestrup FM, Agerso Y, Gerner-Smidt P, et al (2000): Comparison of antimicrobial resistance phenotypes and resistance genes in Enterococcus faecalis and Enterococcus faecium from humans in the community, broilers, and pigs in Denmark. Diagn Microbiol Infect Dis, 37, 127-137.

2. Ahmed MO, Baptiste KE (2018): Vancomycin-resistant enterococci: A review of antimicrobial resistance mechanisms and perspectives of human and animal health. Microb Drug Resist, 25, 590-606.

3. Anonymous (2002): General Directorate of Food and Control. Turkish Food Codex Legislation No: 2002/66. Yem Katkı ve Premikslerin Üretimi, İthalatı, İhracatı, Satış1 ve Kullanımı Hakkında Tebliğ. faolex.fao.org/docs/texts/tur36029.doc. (02 July 2018).

4. Centers for Disease Control and Prevention (2013): Antibiotic Resistance Threats in the United States, 2013. http://www.cdc.gov/drugresistance/pdf/ar-threats-2013508.pdf. (01 July 2018).

5. Clinical and Laboratory Standards Institute (2015): M100-S25 Performance Standards for Antimicrobial Susceptibility Testing; Twenty-Fifth Informational Supplement. www.facm.ucl.ac.be/intranet/CLSI/CLSI2015-M100-S25-original.pdf. (02 July 2018).

6. De Jong A, Bywater R, Butty P, et al (2009): A panEuropean survey of antimicrobial susceptibility towards human-use antimicrobial drugs among zoonotic and commensal enteric bacteria isolated from healthy foodproducing animals. J Antimicrob Chemother, 63, 733744.

7. Dutka Malen S, Evers S, Courvalin P (1995): Detection of glycopeptide resistance genotypes and identification to the species level of clinically relevant enterococci by PCR. J Clin Microbiol, 33, 24-27.

8. Fracalanzza SAP, Scheidegger EMD, dos Santos PF, et al (2007): Antimicrobial resistance profiles of enterococci isolated from poultry meat and pasteurized milk in Rio de Janeiro, Brazil. Mem Inst Oswaldo Cruz, 102, 853-859.

9. French GL (2010). The continuing crisis in antibiotic resistance. Int J Antimicrob Agents, 36, 3-7.

10. Gómez-Gil R, Romero-Gómez MP, García-Arias A, et al (2009): Nosocomial outbreak of linezolid-resistant Enterococcus faecalis infection in a tertiary care hospital. Diagn Microbiol Infect Dis, 65, 175-179.

11. Goncuoglu M, Bilir Ormanci FS, Uludag M, et al (2016): Prevalence and antibiotic resistance of salmonella spp. and Salmonella Typhimurium in broiler carcasses wings and liver. J Food Saf, 36, 524-531.

12. Gousia P, Economou V, Bozidis P, et al (2015): Vancomycin-resistance phenotypes, vancomycin-resistance genes, and resistance to antibiotics of enterococci isolated from food of animal origin. Foodborne Pathog Dis, 12, 214220.

13. Hayes JR, English LL, Carter PJ, et al (2003): Prevalence and antimicrobial resistance of Enterococcus 
species isolated from retail meats. Appl Environ Microbiol, 69, 7153-7160.

14. Jackson CR, Fedorka-Cray PJ, Barrett JB (2004): Use of a genus- and species-specific multiplex PCR for identification of Enterococci. J Clin Microbiol, 42, 35583565 .

15. Kariyama R, Mitsuhata R, Chow JW, et al (2000): Simple and reliable multiplex PCR assay for surveillance isolates of vancomycin-resistant Enterococci. J Clin Microbiol, 38, 3092-3095.

16. Kasimoglu Dogru A, Gencay YE, Ayaz ND (2010): Prevalence and antibiotic resistance profiles of Enterococcus species in chicken at slaughter level; absence of vanA and vanB genes in E. faecalis and E. faecium. Res Vet Sci, 89, 153-158.

17. Ke D, Picard FJ, Martineau F, et al (1999): Development of a PCR assay for rapid detection of Enterococci. J Clin Microbiol, 37, 3497-3503.

18. Kilonzo-Nthenge A, Brown A, Nahashon $\mathrm{SN}$, et al (2015): Occurrence and antimicrobial resistance of enterococci isolated from organic and conventional retail chicken. J Food Prot, 78, 760-766.

19. Klibi N, Said LB, Jouini A, et al (2013): Species distribution, antibiotic resistance and virulence traits in enterococci from meat in Tunisia. Meat Sci, 93, 675-680.

20. López M, Sáenz Y, Rojo-Bezares B, et al (2009): Detection of vanA and vanB2-containing enterococci from food samples in Spain, including Enterococcus faecium strains of CC17 and the new singleton ST425. Int J Food Microbiol, 133, 172-178.

21. Manero A, Blanch AR (1999): Identification of Enterococcus spp. with a biochemical key. Appl Environ Microbiol, 65, 4425-4430.

22. Messi P, Guerrieri E, de Niederhäusern S, et al (2006): Vancomycin-resistant enterococci (VRE) in meat and environmental samples. Int J Food Microbiol, 107, 218222.

23. Pesavento G, Calonico C, Ducci B, et al (2014): Prevalence and antibiotic resistance of Enterococcus spp. isolated from retail cheese, ready-to-eat salads, ham, and raw meat. Food Control, 41, 1-7.

24. Trivedi K, Cupakova S, Karpiskova R (2011): Virulence factors and antibiotic resistance in enterococci isolated from food-stuffs. Vet Med Czech, 56, 352-357.

25. Tyson GH, Nyirabahizi E, Crarey E, et al (2018): Prevalence and antimicrobial resistance of enterococci isolated from retail meats in the United States, 2002 to 2014. Appl Environ Microbiol, 84, e01902-17.

26. Yilmaz ES, Aslantaş O, Onen SP, et al (2016): Prevalence, antimicrobial resistance and virulence traits in enterococci from food of animal origin in Turkey. LWTFood Sci Technol, 66, 20-26. 